\title{
Parallel Outbreaks of Deadly Pathogens (SARS-CoV-2, H5N8, EVD, Black Fungi) around East Africa and Asia in 2021: Priorities for Outbreak Management with Socio-Economic and Public Health Impact
}

\author{
Afroza Khan ${ }^{1,+} \mathbb{D}$, Nayeema Talukder Ema ${ }^{1,+}$, Nadira Naznin Rakhi ${ }^{1}$, Otun Saha ${ }^{1,+} \mathbb{D}$, Tamer Ahamed ${ }^{2}$ \\ and Md. Mizanur Rahaman $1, *$ (D) \\ 1 Department of Microbiology, University of Dhaka, Dhaka 1000, Bangladesh; huma.afroza@gmail.com (A.K.); \\ nayeemaema284@gmail.com (N.T.E.); nadiranrakhi@gmail.com (N.N.R.); otun.saha@gmail.com (O.S.) \\ 2 Norwich Medical School, University of East Anglia, Norwich Research Park, Norwich NR4 7TJ, Norfolk, UK; \\ tamerahamed17@gmail.com \\ * Correspondence: razu002@du.ac.bd; Tel.: +88-017-9658-5290 \\ + Equal Contributions.
}

check for

updates

Citation: Khan, A.; Ema, N.T.; Rakhi, N.N.; Saha, O.; Ahamed, T.; Rahaman, M.M. Parallel Outbreaks of Deadly Pathogens (SARS-CoV-2, H5N8, EVD, Black Fungi) around East Africa and Asia in 2021: Priorities for Outbreak Management with Socio-Economic and Public Health Impact. COVID 2021, 1, 203-217.

https://doi.org/10.3390/covid1010017

Academic Editor: Guglielmo Campus

Received: 13 June 2021

Accepted: 11 August 2021

Published: 13 August 2021

Publisher's Note: MDPI stays neutral with regard to jurisdictional claims in published maps and institutional affiliations.

Copyright: (c) 2021 by the authors. Licensee MDPI, Basel, Switzerland. This article is an open access article distributed under the terms and conditions of the Creative Commons Attribution (CC BY) license (https:/ / creativecommons.org/licenses/by/ $4.0 /)$.
Abstract: Concurrent waves of coronavirus disease, Ebola virus disease, avian influenza A, and black fungus are jeopardizing lives in some parts of Africa and Asia. From this point of view, this review aims to summarize both the socio-economic and public health implications of these parallel outbreaks along with their best possible management approaches. Online databases (PubMed/PMC/Medline, Publons, ResearchGate, Scopus, Google Scholar, etc.) were used to collect the necessary information regarding these outbreaks. Based on the reports published and analyses performed so far, the long-lasting impacts caused by these simultaneous outbreaks on global socio-economical and public health status can be conceived from the past experiences of outbreaks, especially the COVID-19 pandemic. Moreover, prolonged restrictions by the local government may lead to food insecurity, global recession, and an enormous impact on the mental health of people of all ages, specifically in developing countries. Such overwhelming effects have already been reported to be declining the national growth of the economy as well as increasing political insecurity and shortage of basic needs. Although various actions have already been taken, including vaccination, clinical management and further research, social distancing, lockdown, etc., to improve the situation, the emerging variants and associated genetic mutations may make containment difficult, worsening the situation again. So, considering the current mutational dynamics of the pathogens and past experiences, perpetual preparedness along with updated clinical management backed by epidemiological studies and innovative scientific effort are inevitable to combat the simultaneous waves of multiple infectious diseases.

Keywords: COVID-19; EVD; H5N8; BF; socio-economic impact; public health impact; measurements

\section{Introduction}

The world continues to deal with the COVID-19 pandemic that began in Wuhan, China, in December 2019 [1], which has affected 221 countries and territories, causing over 3.5 million deaths by April 2021 [2]. Along with the direct health impact of COVID-19, restrictions (e.g., isolation and social distancing)-induced economic instabilities, including loss of employment, were common in developed and developing/under-developed countries [3,4]. This not only caused a major economic problem worldwide but also severely affected other sectors, including travel and tourism, catering, leisure, etc. [5]. So, it is estimated that the COVID-19 outbreak has reversed the world's economic improvement by 30 years with a surge in the global poverty level [6]. 
While the present data indicate that there is a global decline in the number of new COVID-19 cases and/or deaths, probably due to vaccination and maintaining strict regulations recommended by WHO [7], unfortunately, the emergence of new variants in different countries (India, Brazil) and territories has been a matter of great concern with the risk of reinfections, lower vaccination efficacy, and increased transmissibility [8]. More alarmingly, amidst this COVID-19 situation, a new outbreak of avian influenza subtype, Highly Pathogenic Avian Influenza (HPAI) H5N8, hit the poultry farms and wild birds in Saudi Arabia, which later spread to other countries of the Middle East, Eurasia, and Africa [9] (Figure 1). Additionally, an EVD outbreak was detected concurrently in rural areas of Guinea according to the report on 14 February 2021, which is threatening to spread to other countries unless strict regulations are maintained alongside the COVID-19 restrictions, and as of 18 February, seven cases with five deaths due to Ebola have already been reported [10] (Figure 1). On top of that, the most recent outbreak of black fungus with a $50 \%$ fatality/mortality rate in India is of concern, which is showing a dramatic rise in incidence rates especially among recently treated COVID-19 patients [11,12]. In addition, within only the first 50 days, 1000 cases were reported and more than twenty patients lost their eyesight due to mucormycosis [11]. COVID-19 patients are the most vulnerable to BF infections $[13,14]$. According to the $\mathrm{WHO}$ and other Indian scientists, the recommended application of an overdose of methylprednisolone, use of industrial oxygen, and pre-existence of diabetes in COVID-19 patients led to the severe surge in BF infections in India [15]. However, the most important part is controlling blood sugar levels, along with proper vaccination and medication that can help to control the BF infections among COVID-19 patients [16]. Furthermore, this new epidemic, along with the COVID-19 pandemic, has triggered new challenges in health sectors along with socio-economic and public health. As this might require the removal of eyesight, leading to a patient receiving a social burden, it might also affect patients' mental health, along with being an economical burden [15,16]. The ongoing surge of COVID-19 has already caused a loss of income for approximately 256 million people [13,17]. A study by Shammi et al., 2021 [18], revealed the impact of COVID-19 in Bangladesh on gender discrimination, gender-based violence, business, economy, and education sectors, which was supported by another study by Singh et al., 2021 [19], in India who reported that 59\%, 38\%, and $28 \%$ of people lost job, income, and food security, respectively, due to the surge of ongoing COVID-19 in 2021. This socio-economical scenario can be seen everywhere around the world [17-20]. Moreover, due to the death of 3,538,764 people around the world, it has already affected the amount of working manpower, mainly in food and other basic industrial levels [10,11,17-20]. While the impact of the COVID-19 pandemic is known to all, the other three outbreaks should not be ignored, considering their potential impact on health and living standard. Among the ongoing outbreaks, the currently circulating HPAI H5N8 strain has been reported from poultries in Russia, Europe, China, the Middle East, and North America in 2020-2021 [9]. While no human cases of HPAI H5N8 were found in previous outbreaks [9,21], on 19 February 2021 cases of the first human infections (seven poultry workers) with H5N8 were reported by the WHO H5 Reference Laboratory of the State Research Centre for Virology and Biotechnology VECTOR (FSRI SRC VB VECTOR) Rospotrebnadzor of the Russian Federation $[9,21]$. However, the cases were reported with mild symptoms $[9,21]$, and no human-to-human transmission has been observed so far [22]. Interestingly, since its first emergence in Eastern China in 2010, HPAI H5N8 caused a major outbreak into poultry farms of South Korea in 2014-2015, reintroduced by migratory waterfowl, and spread throughout Asia, Europe, and the United States [23], causing culling of more than 12 million poultry to control the outbreak in South Korea [24]. Again in 2016-2017, more than 29 European countries along with vast regions of Asia [25] were affected by the outbreak of this virus, which was more devastating than the other outbreaks considering the socioeconomic effects. France especially, the world's leading poultry-meat-producing country, suffered huge financial loss due to the culling of about 6.8 million poultry [26] and as 
a whole, approximately 25 million poultry were destroyed in Europe as a part of the preventive measures [22].

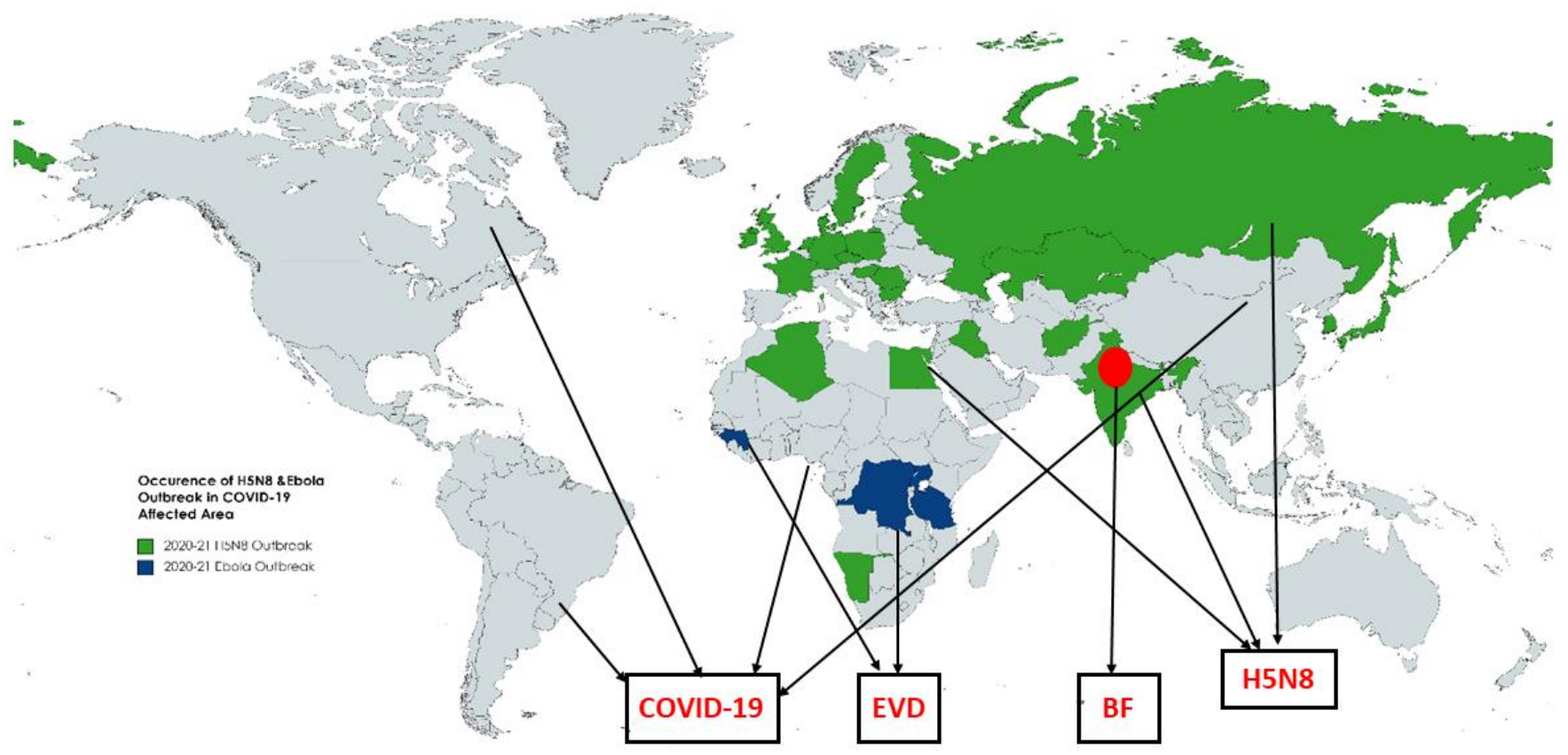

Figure 1. Distribution of H5N8 and Ebola outbreaks in the COVID-19-affected regions across the globe $[8,10,20]$.

On the other hand, previous outbreaks of EVD have a history of causing the extreme hardships of poverty, infrastructure breakdown, rise in endemic diseases due to an overrun healthcare system, crop abandonment, and economic turmoil [27] (Figure 2 and Table 1). The longest-lasting and most fatal one [28] was in West Africa in 2013-2016 which reported 28,646 cases and 11,323 deaths, mostly affecting Sierra Leone, Liberia, and Guinea and spreading across international boundaries of Nigeria, Mali, Senegal, Spain, the UK, the USA, and Italy [29]. The World Bank estimated a cost of 2.2 billion to the most affected countries [30], while the intensive study suggests the combined economic and social burden of the outbreak to be at least 53.19 billion USD globally [31]. Disruption of agricultural products' market chains and trade [32] reduced the productivity of staple crops and the percentage of traders by $12 \%$ and $20 \%$, respectively, which was attributed to severe food insecurity and unemployment (Figure 2 and Table 1). Moreover, this outbreak had taken the lives of over 500 healthcare workers, which forced them to shut off many healthcare facilities [31]. Consequently, the simultaneous outbreak of COVID-19 and EVD in April 2020 in North Kivu triggered a massive economic downturn with worsening food insecurity and increasing poverty [33,34] (Figure 2 and Table 1). Since then, the DCR government along with other African countries have been trying to balance between these two outbreaks, minimizing the greatest obstacles of combined negative economic and socio-political impacts and health impacts of other diseases [35]. However, the most recently reported cases of mucormycosis, commonly known as black fungus, in post-COVID-19 patients still do not have precise data about economic loss, but scientists are predicting its huge impact on socio-economic sectors in the near future, as it is costing the eyes of patients [13-15] (Figure 2 and Table 1). So, the outbreak may further deprive the affected persons of their productivity and employment, making them a burden on society. Furthermore, the cost of COVID-19 has been doubled in India for the treatment of both COVID-19 and mucormycosis, which might lead to financial debt and for them to lose their valuable assets. While the mortality rate of mucormycosis is estimated to be $50 \%$ [36,37], more alarmingly, this outbreak has already spread to its neighboring country Bangladesh from India. So far, only two patients have been detected in Bangladesh and they have already reported their first death [38]. So, such combined outbreaks must have a negative impact 
on developing countries with high population loads in the near future [12]. Thus, the devastating impact to be caused by the combined surge of these deadly infectious diseases can easily be assumed from this preliminary data. Such a catastrophe left a mark in East Africa in 2020, while the combined impact of COVID-19, desert locusts, and floods caused 34 million or more people to starve according to WFP projection, and only in Ethiopia, the GDP might have fallen by $3 \%$ in 2019/2020 [20]. A better understanding of the parallel effect on socio-economic and public health of three deadly pathogens during the COVID-19 pandemic is critical for effective social/mental/health/economical management, food security, food safety, treatment, and stifle of SARS-CoV-2. It is, therefore, necessary to strengthen the investigation of the co-effect of other diseases during the COVID-19 pandemic. Moreover, regarding COVID-19, several issues such as social destruction, mental wreckage, economic erosion, environmental erosion, useful strategies to prevent disease spread, and effective drug treatments are still largely unknown. However, the possibility of co-effects and/or parallel effects with other deadly pathogens including EVD, $\mathrm{BF}$, and $\mathrm{H} 5 \mathrm{~N} 8$ are not yet clearly understood. The association of these reported pathogens, causing parallel destruction, should be an important concern for socio-economic and public health management during the COVID-19 pandemic. So, the present data of the combined effect of these infectious diseases urge immediate attention from the scientific community, international leaders, and general people to acknowledge its socio-economic and public health impact, especially in low-resource settings, and to develop a policy to combat such waves of multiple outbreaks in the near future. This article aims to summarize the detrimental effects of these infectious viral and/or fungal agents observed in recent times in co-relation with past experiences.

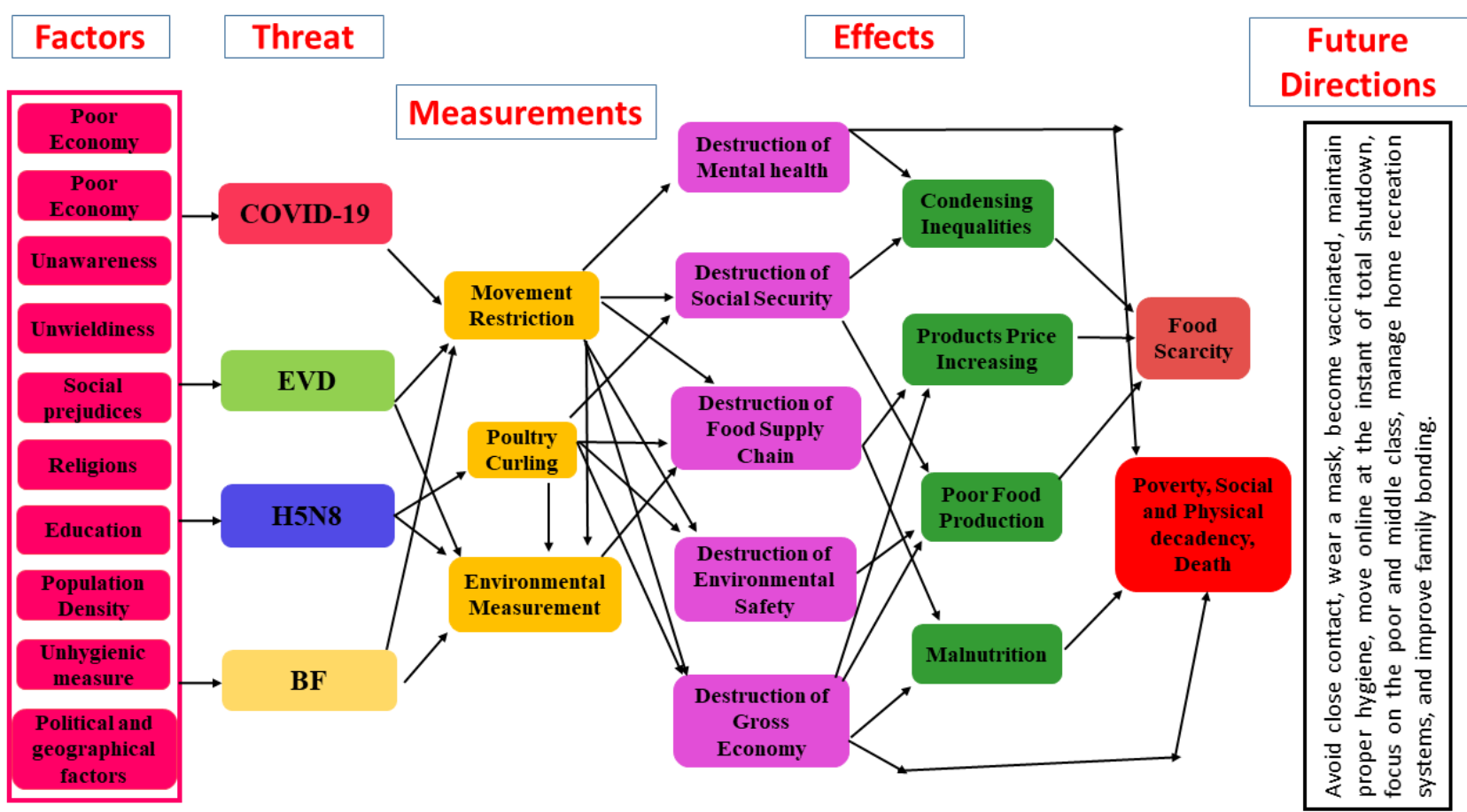

Figure 2. The dynamics of the tetra-threat outbreak (COVID-19, EVD, H5N8, and black fungus) that threatens both the socioeconomical and public health sectors. Here, EVD—Ebola virus, BF-black fungus. Each arrow indicates the consequence of each incidence. Arrow indicates the possible outcome from the previous arising issues from each threat. According to the tetra-threat model, threats are identified first, followed by the possible factors contributing to their dissemination, measurements, all possible effects, and possible therapeutic strategies for reduction. 
Table 1. Possible consequence of trio (COVID-19, H5N8, and black fungus) outbreak in India.

\begin{tabular}{|c|c|c|c|}
\hline Outbreak & 1st Line Effects & 2nd Line Effects & Adverse Effect \\
\hline Social & $\begin{array}{l}\text { Destruction of social execution } \\
\text { Vulnerable groups become helpless } \\
\text { Loss of lives } \\
\text { Education system collapse }\end{array}$ & $\begin{array}{c}\text { Community imbalance } \\
\text { Imbalance of all social activities } \\
\text { Unethical activity by } \\
\text { vulnerable groups } \\
\text { Insecurity on future } \\
\text { generation educations }\end{array}$ & $\begin{array}{c}\text { Vulnerable groups victimized } \\
\text { Insectary in community } \\
\text { Political crisis } \\
\text { Destruction of total } \\
\text { education systems }\end{array}$ \\
\hline Economic & $\begin{array}{c}\text { Scarcity of basic materials including } \\
\text { oxygen, medicine, etc. } \\
\text { Rise of product prices } \\
\text { Country GDP decrease } \\
\text { Trading with neighboring country } \\
\text { will be disturbed } \\
\text { Loss of jobs } \\
\text { Unemployment problems increase }\end{array}$ & $\begin{array}{l}\text { Loss of livelihoods } \\
\text { Destructions of local } \\
\text { supply capacity } \\
\text { Country's economy fall }\end{array}$ & $\begin{array}{c}\text { Increased poverty } \\
\text { Higher scarcity of foods } \\
\text { Breakdown of financial chain }\end{array}$ \\
\hline Public Health & $\begin{array}{c}\text { Health service insecurity } \\
\text { Impairment of basic needs of life } \\
\text { Health destruction of children and } \\
\text { pregnant women } \\
\text { Development of prejudice } \\
\text { Loss of vision ability }\end{array}$ & $\begin{array}{c}\text { Crisis in health sectors } \\
\text { Development of abnormal children } \\
\text { Environmental crisis } \\
\text { Disruption of working ability }\end{array}$ & $\begin{array}{l}\text { Loss of valuable lives } \\
\text { Increase in abnormal mental health } \\
\text { Malnutrition } \\
\text { Loss of total working ability }\end{array}$ \\
\hline
\end{tabular}

\section{Methodology of the Review and Its Rationale}

Approximately more than three to five thousand reports have been published so far individually on origin, genomics, evolution, molecular diagnosis, vaccine, economic and/or social effects, and the public health effect of SARS-CoV-2, EVD, HPAI, and BF $[3,20,25,26]$. Moreover, few of them have been focused on the individual and/or combined (two) public and/or social impact of all four reported pathogens. However, a comprehensive review on individual and combined ongoing and future effects of other reported pathogens with COVID-19 and their underlying therapeutic strategies are lacking. Therefore, in this review, we focused on the all possible past, present, and future socio-economic impacts along with public health impacts and possible managements of "Tetra Threats" of COVID-19, EVD, black fungus, and H5N8 in East Africa and Asia through a rigorous literature survey. The concept and all possible social, economic, and public health co-effects of all four deadly pathogens are illustrated in the introductory sections. The following databases were used to collect information: PubMed/PMC/Medline, BioRxiv, medRxiv, National Institute of Helath (NIH), World Health Organization pandemic blog, Global Health, ORCID, Publons, Indian citation index, ResearchGate, Scopus, Google Scholar, Google, ScienceOpen, Chinese Social Science Citation Index, COVID-19 vaccine and therapeutics tracker (https:/ / biorender.com/COVID-vaccine-tracker accessed on 10 June 2021), and Science Direct. The terms and keywords including socioeconomic impacts, public health impacts, management, pandemic, epidemic, and possible destruction were used for searching in conjunction with SARS-CoV-2 infection, COVID-19 pandemic, Ebola infections, H5N8 outbreaks, black fungus, Asia, world outbreak, and Africa. All the relevant journals, book chapters, conference papers, online newspapers, local/international media, and organization-based news articles were taken into account for this study. A total of more than 100 relevant sources of information from the initial 431 search results were used in this review. The literature search was performed through screening of titles, abstracts, methodology, specific keywords, and full articles for expendiency. Most interestingly, in our review sections we tried to follow the "Tetra threat Model" that Ghemawat proposed, which helped to correlate the factors behind each threat followed by the possible impact of them on both social and economic sectors, and reduction strategy [39,40]. The possible and proposed tetra-threat effect on social, economic, and public health concurrent with SARS-CoV-2 infections is represented in Figure 2. 


\section{Results and Discussion}

\subsection{Possible Social Complications of Outbreaks in the Near Future}

Based on the past experiences with these outbreaks, we can speculate the dire consequences and global impact of the combined effects of EVD, COVID-19, BF, and HPAI. Social distancing might be necessary to contain these deadly pathogens, but it comes with panic and socio-economic collapse [41]. However, considering vaccination, pandemic control measures, and the re-emergence of new variants, global economic activity might reduce to $4 \%$ in 2021 and $3.8 \%$ in 2022 , or on the darker side, might face downfall with below-potential growth by 2022 if the situation becomes worse [17,19,33]. Additionally, due to lockdown and other restrictions, mental health would wither away mainly because of unemployment, which may also lead to crime, burglary, and fraud business [42-45]. A study conducted in South Africa revealed that $24 \%$ and $30 \%$ of adults suffered from depression and lost jobs, respectively, due to the long lockdown [45]. In another study by Fana et al., 2020, they reported the Sevier effect of lockdown on employment in Spain, Italy, and the UK [46]. Another study by Nivette et al., 2021, reported a significant increase in crime among urban people in 23 countries of the Americas, Europe, the Middle East, and Asia [47]. Such long-time social erosion will also affect the total social bonding and systems. Furthermore, affording medical care will be difficult for low-income people, while an avian influenza outbreak would cull domestic birds and disrupt the food supply chain (Figure 2). So, the mortality and morbidity rate would increase not only due to diseases but also due to malnutrition-associated complexities [42,43]. The world would face severe poverty, which is also currently evident with the COVID-19 outbreak [48].

\subsection{Impact of Each Outbreak on Public Health}

On 7 February, positive cases of H5N8 infection were detected among poultry workers in Russia [49]. Among them, five (aged 29-60) were female workers involved in response operations to contain the outbreak [50]. The co-relation between patients' age and H5N8 infection has not been proved yet, which was already proven in the case of EVD incidence, where the age group more than 35-44 years old was more vulnerable than the younger one [51]. Another study calculated Ebola virus disease risk among different age groups and stated the attack rate for children less than 2 years of age, 5-14 years of age, and $\geq 30$ years of age to be $43 \%, 30 \%$, and $>60 \%$, respectively. In contrast, women attending to sick people and health care workers' conditions might contribute to the higher risk in middle-aged people [52]. However, the risk of acquiring Ebola was similar for both males and females [52]. On the contrary, COVID-19 infection comes with a greater risk rate, severity, and mortality rate among elderly people due to immune impairment with increasing age [53]. Children are less infected by COVID-19, or in most cases, they remain asymptomatic [53]. Reportedly, age-dependent susceptibility to COVID-19 infection and probability of acquiring clinical symptoms is $20 \%$ for young children and $70 \%$ in older adults [54]. Meanwhile, among children, infants are reported to be more vulnerable to COVID-19 infections, with 10.7\% severe cases [55]. According to recent national data of Asia and African countries, with demographic shift [56], COVID-19 infections are largely increasing in younger adults [57]. Among almost 7 million COVID-19 cases, $76 \%$ of them are represented by young adults (age below 65 years old and 18-29 years), contributing to the largest proportion, though the death rate still happens to be greater among older people $[53,54]$. Possible risk factors for COVID-19 infections being severe in young adults are pre-existing health conditions such as being overweight, heart disease, type 2 diabetes, unhealthy lifestyle, smoking, etc. [56], which is also true in the case of black fungus attack. However, another study calculated that age does not contribute to COVID-19 susceptibility; rather, it might just affect disease severity [58]. In the case of pregnancy, Ebola is associated with a high mortality rate of $72 \%$ [59] to $100 \%$ [60]. However, no evidence has been reported regarding if pregnant women are alarmingly susceptible to Ebola infection or not, but it certainly has led to miscarriage and neonatal death in almost every case [60], with one review concluding with a speculation of transmission risk of Ebola 
to baby through pregnancy-related fluid and breast milk [59]. However, susceptibility to SARS-CoV-2 infection is reported in pregnant women, in whom clinical complications are associated with [61] their first and third trimester and downregulation of their immune system [62] (Figure 2 and Table 1). This immune suppression is associated with black fungus infection during post-COVID events, especially in cases of steroid treatment and in diabetic patients [63]. So far, among all of the identified BF cases, $70 \%$ were reported in the various states of India highly struggling with the COVID-19 surge [14]. Reports say that COVID-19 patients confirm the lower levels of lymphocytes, particularly helper $\mathrm{T}$ cells and cytotoxic $T$ cells, which lead to immunosuppression and cause BF infections [64]. In another report, it was expressed that the increased use of steroids reduces the phagocytic activity of neutrophils and macrophages in COVID-19 patients, leading them being the most vulnerable to BF infections [65]. Most alarmingly, more than $80 \%$ of infected patients need surgery, whereas in the US, there was reported a more than $54 \%$ mortality rate due to this mucormycosis in COVID-19 patients [66]. In India, 94\% of patients having diabetes along with COVID-19 were reported as BF positive and faced the most severe side of this infection [14]. Due to these alarming situations, many states of India have declared this as public health emergency $[65,66]$. No details regarding the epidemiological data about BF are available around the world so far. On top of that, if these three outbreaks prevail, the public health sector will be the hardest-hit area, because healthcare facilities and resources are limited in underdeveloped countries [34]. Moreover, less outpatient attendance will be possible for the fear of contracting disease, leaving the people with other diseases such as malaria, HIV, etc., with no/minimal medical attention [49]. Additionally, community health and the global economy would be severely disrupted.

\subsection{Present Containment Strategies of All Outbreaks}

The tendency of frequent re-assortment, genetic mutation, and evolution of emerging pathogens threatens to evolve into a new strain that might be transmitted to humans and human-to-human, or even human to animals or animals to human [22,67-70]. Each outbreak being monitored is therefore essential in identifying new strains to avoid the risk of an adverse situation and to minimize the pathogenic transmission as much as possible.

Firstly, this is especially a concern for HPAI H5 viruses, as they can transmit silently without any severe clinical symptoms in their wild hosts [71], which forces us to pay attention to the Russian cases to identify and monitor exposed individuals, test suspected cases, and prevent their spread to the community. To halt the propagation of the virus, millions of birds were mass slaughtered based on previous experiences with the H5N1 outbreak in 2008 [72]. To contain this virus, some 600,000 poultry were killed in France alone [73]. Along with this activity, affected poultry flocks must be quickly destroyed, and measures put in place to protect workers, establishing a quick control and surveillance plan. Antiviral prophylaxes are being considered and recommended as a contaminant measure for this deadly pathogen [74]. However, only the culling of wild birds alone is not an effective way to prevent the dissemination of such a super-spreader [72], which led the researchers to make progress in searching for vaccines. As a result of such devotion of world-renowned researchers, many candidate vaccines have already been introduced which showed significant protective results against $\mathrm{H} 5$ strains [75]. Still, no vaccine has been approved by the FDA for the treatment of $\mathrm{H} 5 \mathrm{~N} 8$ alone. Moreover, earlier experiences show that antiviral drugs are $50 \%$ to $70 \%$ effective in the treatment of reported viruses [75]. Currently available antiviral drugs approved for the treatment of influenza are M2 ion channel blockers and neuraminidase (NA) inhibitors [76]. Along with human vaccination, vaccination for domestic poultry can be considered. Several vaccine candidates were developed and, after multiple trials, several vaccines were considered effective against HPAI H5N8, including recombinant $\mathrm{H} 5$ and $\mathrm{H} 7$ bivalent inactivated vaccines, modified vaccinia virus Ankara (MVA)-based $\mathrm{H} 5$ vaccine, and a single dose of inactivated oilemulsion bivalent H5N8/H5N1 vaccine [77-79], followed by antibody-based therapies [80]. Along with all possible attempts, the global initiative on sharing avian influenza data 
(GISAID) has set up a platform to gather and share all available sequence data for providing a better understanding of the epidemiology and evolution of the currently circulating viruses, including H5N8. Additionally, flu surveillance laboratories have been established in more than 50 countries worldwide [81].

However, lately Ebola-affected African countries have been trying to adopt control measures and interventions to mitigate the Ebola outbreak [26,29]. According to the mode of transmission of EVD, physical contact with the patient's blood, body fluids (saliva, semen, and breast milk), conjunctival and vaginal discharges, and sexual intercourse are majorly responsible for EVD transmission, whereas conventional burial procedures were responsible for more than 68\% of transmission of EVD in Guinea in 2014 [82]. Moreover, the consumption of infected animal meat, such as bats or chimpanzees, is also responsible for transmission to humans through its zoonotic nature [83]. From the mode of transmission, it has been proved that avoiding unsafe traditional burial, avoiding unprotected sex, avoiding dead animal handling, contact tracing, personal hygiene, fruits and vegetables cleanliness, environmental safety management, etc., are the major contaminant measures for the control and prevention of EVD in the affected areas, along with proper vaccination and medication [82]. Moreover, community engagement with strong international support has been greatly helpful for effective outbreak response. Interventions that helped to control the 2013-2016 Ebola outbreak were effective case management, contact tracing, quick diagnosis and treatment, isolation of suspected and confirmed cases, strong infection control, safe burial, and establishing an Ebola treatment centre (ETC) by the United Nations (UN). Additionally, research on vaccines and therapeutics development and active genomic surveillance helped to make decisions for Ebola response [29]. Moreover, the European Union (EU) contributed nearly 1.8 billion to provide more medical and support staff to West Africa during EVD outbreak. In Europe, the EU made policies to combat this global health emergency and set up an evacuation system to provide resources to international health workers [84]. Strategies that have helped contain the Ebola virus during the 2018-2020 outbreak in the Democratic Republic of Congo include deploying a multidisciplinary rapid response team to support Ebola case management, providing patients with equitable access to advanced therapeutics Mab114, REGN-EB3, and ZMAPP, vaccinating over 303,000 people with the highly effective rVSV-ZEBOV-GP vaccine [85], introducing novel Ebola diagnostic tools as well as applying new technologies such as whole-genome sequencing, and building community engagement alongside new surveillance programs [86]. Along with the advanced therapeutics and approaches, several vaccines and treatments against Ebola virus are under clinical trial, including rVSV-ZEBOV or Ervebo [87], which was proved to be 100\% protective against EVD [88]. It can be administered in people of 18 years of age or above [88]. In July 2020, another vaccine, a two-dose regimen of Ad26.ZEBOV and MVA-BN-Filo under the brand name Zabdeno/Mvabea, was approved for medical use by the European Union, developed by Johnson and Johnson [89]. Reverse vaccinology approaches utilizing immunoinformatics are being exploited recently to produce vaccines against Ebola virus strains, conferring good performance in silico [90]. Like vaccines, until 2020, there was no approved drug or therapy for EDV treatment. Treatment mostly focused on supportive care therapy [29]. Supportive care includes oral rehydration that contains electrolytes [91], preventing the complications of shock and fluid resuscitation in Ebola-infected people [29,92]. Several anti-Ebola therapeutics, such as anti-viral drugs, monoclonal antibodies, anti-inflammatory agents, convalescent plasma, etc., were proposed and evaluated during Ebola virus outbreak to contain and reduce the risk of the virus [29,93]. Inmazeb, also called REGN-EB3, a combination of three monoclonal antibodies, and Ebanga (Mab114), a single monoclonal antibody, were the only two drugs approved for Ebola treatment by the US Food and Drug Administration (FDA) in late 2020 [94], which were previously used in a randomized control trial during the 2018-2020 Ebola outbreak in the Democratic Republic of Congo and resulted in a high survival rate [90]. Another therapeutic, called ZMapp, a cocktail of 
three monoclonal antibodies, also proved to be superior to standard care for Ebola virus disease treatment [93].

On the contrary, the antiviral drug remdesivir, though proven to be good in preclinical studies, did not manage to reduce Ebola transmission effectively. However, on the other hand, some drugs, such as remdesivir, have proved effective against COVID19 infections [62]. Remdesivir, ZMapp, Mab114, and REGN-EB3 were associated with $53.1 \%, 49.7 \%, 35.1 \%$, and $33.5 \%$ mortality rates, respectively, in one study [95]. Additionally, remdesivir, along with ZMapp treatment, benefited newborn babies against Ebola infection [93]. Considering all the reports and the overall positive effects related to them, MAB114, REGN-EB3, remdesivir, and ZMapp were recommended by the WHO and health authorities in the 2018-2019 Ebola outbreak in the DRC [93,95]. Notably, TKM-Ebola, an intravenous formulation of small interfering RNA (siRNA) which inhibits Ebola L protein, VP24, and VP35 proteins, showed in vitro efficacy against Ebola and was authorized by the FDA for emergency use [92]. Chloroquine and cationic amphiphiles such as amiadarone are also reported to be good as prophylactic agents for Ebola virus infection, where antivirals or vaccines are not available [92]. For critically ill patients with Ebola infection, oxygen supplementation, mechanical ventilation, or renal replacement therapy have been shown to reduce death rates [96]. Additionally, WHO stated convalescent plasma transfusion can be used to treat Ebola infection [92], as it decreases Ebola viral load by increasing anti-Ebola virus antibody level [88]. They might be an aid to the public health response for both COVID-19 and EVD outbreaks in the future and a way to decrease the socio-economic impact on already vulnerable citizens right now [35].

Meanwhile, recognizing COVID-19 as a pandemic, all countries are trying to reduce transmission of SARS-CoV-2 by testing and treating infected patients, restricting large gatherings, stopping flights and public transport, closing schools, colleges, and non-essential workplaces, and maintaining lockdown measures [97,98]. Physical distancing has been reported to have a profound impact with an overall reduction in COVID-19 incidence of $13 \%$ globally [99]. Moreover, early screening, wearing a mask, frequent hand washing, early diagnostics, social distancing, respiratory hygiene (i.e., cover their cough) practicing, and lockdown are now considered the major containment measures of the COVID-19 pandemic, which have been proven as an effective by various previous studies [100]. Currently, there are several vaccines approved by distinct regulatory bodies for mass vaccination. WHO issued Pfizer, AstraZeneca/Oxford, and Ad26.CoV2.S vaccines, working with partners for safe and effective vaccine equity for billions of people [101].

However, due to widespread circulation, the virus has undergone a significant amount of mutation that has led to the emergence of new variants. These are the UK (VOC 202012/01), South Africa (501Y.V2), Brazil (P.1), etc. Existing vaccines are expected to provide a degree of protection against these variants. However, the WHO and other regulators are monitoring the data carefully to suggest changes needed to combat these new variants [102]. Unlike vaccines, there is no specific treatment enlisted for COVID-19. In general, for mild to severe cases of infection, antiviral drugs, antibiotics, steroids, antiinflammatory drugs, low-molecular-weight heparin, biological agents such as hyperimmune immunoglobulins, and convalescent plasma are used [103]. According to guidelines issued by the National Health Commission and State, the administration of several drugs has been recommended for COVID-19 treatment, including lopinavir, ritonavir, arbidol, chloroquine phosphate, ribavirin, remdesivir, tocilizumab, etc. Chloroquine phosphate, a potential antiviral drug, helps to inhibit pneumonia exacerbation and reduce disease course during COVID-19 infection [104], although hydroxychloroquine has been proven to be better in fighting the infection than chloroquine in the context of dose-dependent toxicity profile [105]. Azithromycin, along with hydroxychloroquine, is reported to be useful for virus removal in COVID-19 infection [105]. Similarly, combined use of lopinavir and ritonavir has shown potential antiviral activity with a positive outcome in the treatment of SARS-CoV-2-infected patients [86]. Remdesivir, observed to inhibit SARS-CoV-2 at low concentrations, was stated to be the first authorized investigational therapeutic for use in 
treating SARS-CoV-2 infection [35]. Additionally, WHO has authorized the use of dexamethasone for anti-inflammatory purposes in critical conditions of COVID-19 patients [106]. For critical conditions, tocilizumab, a recombinant monoclonal immunoglobulin G1, also showed a satisfactory effect against the infection [107]. Interferon-alpha and Janus-kinase inhibitor are also recommended, as they showed a significant decrease in SARS-CoV-2 virus replication [108], mortality rate, and ICU admission of COVID-19 patients [109]. Convalescent plasma transfusion might also be a promising treatment against COVID-19, as its use reduces mortality in critically ill patients, increasing neutralizing antibody titers and decreasing SARS-CoV-2 viral RNA [110,111]. Considering COVID-19-infected patients to have increased risk of venous thromboembolism (VTE), anti-coagulative therapy should be given importance in the treatment [110].

Most dramatically, black fungus, bearing a more than $50 \%$ mortality rate, has no effective treatment, except antifungals (amphotericin B, amphotericin deoxycholate), antibiotics, intravenous (IV) medication, or surgery [14]. Although, regular blood sugar measurement and control, controlled hyperglycemia, reduced consumption of steroids during COVID-19 infection, rapid control of diabetic ketoacidosis, reduced consumption of immunomodulating drugs, antifungal prophylaxis, radio imaging, clinical monitoring of fungal progression, proper cleaning of ventilators, disinfected personal protective equipment, and proper hygiene maintenance are now used as control and preventive measures of BF infection [14,15]. Importantly, utilizing its experience of Ebola outbreak, the Democratic Republic of Congo has established a multisectoral public health approach for community-based screening, testing, contact tracing, risk communication, community engagement, and case management to fight against COVID-19 and other deadly super-contagious pathogens [63]. WHO, along with national authorities, continuously monitors disease control activities including epidemic and genomic surveillance, strategic testing and sequencing of new variants of concern (VOC), and assessing vaccine efficacy. Infection and Prevention Control (IPC) undertaken by WHO has been proven to be effective to reduce transmission and death due to COVID-19 [2].

\section{Conclusions}

"Tetra Threats" of COVID-19, H5N8, EVD, and black fungi are concerning with regard to their socio-economic and public health impacts, while their management is still challenging at this initial stage. The worst sufferers are especially the countries with simultaneous outbreaks of more than one agent of these tetra threats, notably in some parts of Africa and Asia. More importantly, apart from the direct impact of these outbreaks, the indirect effects induced from the containment strategies implied (e.g., lockdown, social distancing) and the impacts on the financial and the mental condition of infected and/or even noninfected individuals are significant. So, despite the current advancement in treatment and control strategies of these outbreaks, further studies, including proper epidemiological surveillance studies, are needed to devise effective containment strategies amenable to customization, according to pre-existing crises and vulnerabilities of individual countries around the world.

Author Contributions: A.K., N.T.E. and O.S. carried out the studies (data collection and data analysis). A.K., N.T.E., N.N.R., T.A. and O.S. drafted the manuscript. O.S. and M.M.R. developed the hypothesis, supervised the whole work and M.M.R., N.N.R. and O.S. critically reviewed the drafted manuscript. All authors have read and agreed to the published version of the manuscript.

Funding: This research received no external funding.

Acknowledgments: We acknowledge the Ministry of Science and Technology, Bangladesh for Special Allocation Project 2019-2020 to M.M.R. and Bangladesh Bureau of Education Information and Statistics (BANBEIS) for research grant No. LS2019935 to M.M.R. The authors also acknowledge the grant funding from Bangabandhu Science and Technology Fellowship Trust (O.S., fellowship) and the research fund from the University Grants Commission to N.N.R.

Conflicts of Interest: The authors declare that the research was conducted in the absence of any commercial or financial relationships that could be construed as a potential conflict of interest. 


\section{References}

1. Rahman, M.S.; Hoque, M.N.; Islam, M.R.; Akter, S.; Alam, A.R.; Siddique, M.A.; Saha, O.; Rahaman, M.M.; Sultana, M.; Crandall, K.A.; et al. Epitope-based chimeric peptide vaccine de-sign against S, M and E proteins of SARS-CoV-2, the etiologic agent of COVID-19 pan-demic: An in silico approach. PeerJ. 2020, 8, e9572. [CrossRef]

2. Islam, A.; Sayeed, A.; Rahman, K.; Zamil, S.; Abedin, J.; Saha, O.; Hassan, M.M. Assessment of basic reproduction number (R0), spatial and temporal epidemiological determinants, and genetic characterization of SARS-CoV-2 in Bangladesh. Infect. Genet. Evol. 2021, 92, 104884. [CrossRef]

3. Nicola, M.; Alsafi, Z.; Sohrabi, C.; Kerwan, A.; Al-Jabir, A.; Iosifidis, C.; Agha, M.; Agha, R. The so-cio-economic implications of the coronavirus and COVID-19 pandemic: A review. Int. J. Surg. 2020, 78, 185-193. [CrossRef] [PubMed]

4. Rahaman, M.M.; Saha, O.; Rakhi, N.N.; Chowdhury, M.M.; Sammonds, P.; Kamal, A.M. Overlap-ping of locust swarms with COVID-19 pandemic: A cascading disaster for Africa. Pathog. Glob. Health 2020, 114, 285-286. [CrossRef] [PubMed]

5. Ceylan, R.F.; Ozkan, B.; Mulazimogullari, E. Historical evidence for economic effects of COVID-19. Eur. J. Health Econ. 2020, 21, 817-823. [CrossRef]

6. Saha, O.; Rakhi, N.N.; Sultana, A.; Rahman, M.M.; Rahaman, M.M. SARS-CoV-2 and COVID-19: A Threat to Global Health Discov. Rep. 2020, 3, e13. [CrossRef]

7. Baker, H.A.; Safavynia, S.A.; Evered, L.A. The 'third wave': Impending cognitive and function-al decline in COVID-19 survivors. Br. J. Anaesth. 2021, 126, 44-47. [CrossRef]

8. Towhid, S.T.; Rakhi, N.N.; Arefin, A.S.; Saha, O.; Mamun, S.; Moniruzzaman, M.; Rahaman, M.M. COVID-19 and the Cardiovascular System: How the First Post-Modern Pandemic 'Weak-ened'our Hearts. Discov. Rep. 2020, 3, e15. [CrossRef]

9. Lewis, N.S.; Banyard, A.C.; Whittard, E.; Karibayev, T.; Al Kafagi, T.; Chvala, I.; Byrne, A.; Akberovna, S.M.; King, J.; Harder, T.; et al. Emergence and spread of novel H5N8, H5N5 and H5N1 clade 2.3.4.4 highly pathogenic avian influenza in 2020. Emerg. Microbes Infect. 2021, 10, 148-151. [CrossRef]

10. Aborode, A.T.; Tsagkaris, C.; Jain, S.; Ahmad, S.; Essar, M.Y.; Fajemisin, E.A.; Adanur, I.; Uwishema, O. Ebola Outbreak amid COVID-19 in the Republic of Guinea: Priorities for Achieving Control. Am. J. Trop. Med. Hyg. 2021, 104, 1966-1969. [CrossRef]

11. Dyer, O. Covid-19: India sees record deaths as "black fungus" spreads fear. BMJ 2021, 373, n1238. [CrossRef] [PubMed]

12. Mucormycosis: The 'Black Fungus' Maiming Covid Patients in India. Available online: https://www.bbc.com/news/worldasia-india-57027829 (accessed on 18 July 2021).

13. Black Fungus Epidemic Triggers New Challenge in India. Available online: https://www.aa.com.tr/en/asia-pacific/blackfungus-epidemic-triggers-new-challenge-in-india/2253074 (accessed on 18 July 2021).

14. Rocha, I.C.N.; Hasan, M.M.; Goyal, S.; Patel, T.; Jain, S.; Ghosh, A.; Cedeño, T.D.D. COVID-19 and Mucormycosis Syndemic: Double Health Threat to a Collapsing Healthcare System in India. Trop. Med. Int. Health 2021, 1-3. [CrossRef]

15. About Mucormycosis I Mucormycosis I CDC. Available online: https://www.cdc.gov/fungal/diseases/mucormycosis/definition. html (accessed on 24 May 2021).

16. Over 28,200 “Black Fungus" Cases Recorded in India. Available online: https://www.aa.com.tr/en/asia-pacific/over-28-200 -black-fungus-cases-recorded-in-india/2266396 (accessed on 9 June 2021).

17. Josephson, A.; Kilic, T.; Michler, J.D. Socioeconomic impacts of COVID-19 in low-income countries. Nat. Hum. Behav. 2021, 5, 557-565. [CrossRef] [PubMed]

18. Shammi, M.; Doza, B.-D.; Islam, A.R.M.T.; Rahman, M. Strategic assessment of COVID-19 pandemic in Bangladesh: Comparative lockdown scenario analysis, public perception, and management for sustainability. Environ. Dev. Sustain. 2021, 23, 6148-6191. [CrossRef]

19. Singh, K.; Kondal, D.; Mohan, S.; Jaganathan, S.; Deepa, M.; Venkateshmurthy, N.S.; Jarhyan, P.; Anjana, R.M.; Narayan, K.V.; Mohan, V.; et al. Health, psychosocial, and economic im-pacts of the COVID-19 pandemic on people with chronic conditions in India: A mixed methods study. BMC Public Health 2021, 21, 1-5. [CrossRef] [PubMed]

20. Kassegn, A.; Endris, E. Review on socio-economic impacts of 'Triple Threats' of COVID-19, desert locusts, and floods in East Africa: Evidence from Ethiopia. Cogent Soc. Sci. 2021, 7, 1885122. [CrossRef]

21. Nagy, A.; Černíková, L.; Kunteová, K.; Dirbáková, Z.; Thomas, S.S.; Slomka, M.J.; Dán, Á.; Varga, T.; Máté, M.; Jiřincová, H.; et al. A universal RT-qPCR assay for "One Health" detection of influenza A viruses. PLoS ONE 2021, 16, e0244669. [CrossRef]

22. Adlhoch, C.; Dabrera, G.; Penttinen, P.; Pebody, R.; On Behalf of Country Experts. Protective Measures for Humans against Avian Influenza A(H5N8) Outbreaks in 22 European Union/European Economic Area Countries and Israel, 2016-2017. Emerg. Infect. Dis. 2018, 24, e180269. [CrossRef]

23. Kwon, J.H.; Lee, D.H.; Swayne, D.E.; Noh, J.Y.; Yuk, S.S.; Erdene-Ochir, T.O.; Hong, W.T.; Jeong, J.H.; Jeong, S.; Gwon, G.B.; et al. Highly pathogenic avian influenza A (H5N8) viruses rein-troduced into South Korea by migratory waterfowl, 2014-2015. Emerg. Infect. Dis. 2016, 22, 507. [CrossRef]

24. Ku, K.B.; Park, E.H.; Yum, J.; Kim, J.A.; Oh, S.K.; Seo, S.H. Highly pathogenic avian influenza A (H5N8) virus from waterfowl, South Korea, 2014. Emerg. Infect. Dis. 2014, 20, 1587. [CrossRef]

25. Briand, F.X.; Niqueux, E.; Schmitz, A.; Martenot, C.; Cherbonnel, M.; Massin, P.; Kerbrat, F.; Chatel, M.; Guillemoto, C.; GuillouCloarec, C.; et al. Highly Pathogenic Avian Influenza A (H5N8) Virus Spread by Short-and Long-Range Transmission, France, 2016-17. Emerg. Infect. Dis. 2021, 27, 508. [CrossRef] 
26. Guinat, C.; Nicolas, G.; Vergne, T.; Bronner, A.; Durand, B.; Courcoul, A.; Gilbert, M.; Guérin, J.-L.; Paul, M.C. Spatio-temporal patterns of highly pathogenic avian influenza virus subtype H5N8 spread, France, 2016 to 2017. Eurosurveillance 2018, $23,1700791$. [CrossRef] [PubMed]

27. Redding, D.W.; Atkinson, P.M.; Cunningham, A.A.; Iacono, G.L.; Moses, L.M.; Wood, J.L.; Jones, K.E. Impacts of environmental and socio-economic factors on emergence and epidemic poten-tial of Ebola in Africa. Nat. Commun. 2019, 10, 4531. [CrossRef]

28. Baseler, L.; Chertow, D.S.; Johnson, K.M.; Feldmann, H.; Morens, D.M. The pathogenesis of Ebo-la virus disease. Annu. Rev. Pathol. Mech. Dis. 2017, 12,387-418. [CrossRef]

29. Coltart, C.E.M.; Lindsey, B.; Ghinai, I.; Johnson, A.M.; Heymann, D.L. The Ebola outbreak, 2013-2016: Old lessons for new epidemics. Philos. Trans. R. Soc. B Biol. Sci. 2017, 372, 20160297. [CrossRef]

30. Furuyama, W.; Marzi, A. Ebola Virus: Pathogenesis and Countermeasure Development. Annu. Rev. Virol. 2019, 6, 435-458. [CrossRef] [PubMed]

31. Huber, C.; Finelli, L.; Stevens, W. The Economic and Social Burden of the 2014 Ebola Outbreak in West Africa. J. Infect. Dis. 2018, 218, S698-S704. [CrossRef] [PubMed]

32. Ali, Z.; Green, R.; Zougmoré, R.B.; Mkuhlani, S.; Palazzo, A.; Prentice, A.M.; Haines, A.; Dangour, A.D.; Scheelbeek, P.F. Long-term impact of West African food system responses to COVID-19. Nat. Food 2020, 1, 768-770. [CrossRef]

33. Stoop, N.; Desbureaux, S.; Kaota, A.; Lunanga, E.; Verpoorten, M. Covid-19 vs. Ebola: Impact on households and small businesses in North Kivu, Democratic Republic of Congo. World Dev. 2021, 140, 105352. [CrossRef]

34. Islam, M.; Rakhi, N.N.; Islam, O.K.; Saha, O.; Rahaman, M. Challenges to be considered to evaluate the COVID-19 preparedness and outcome in Bangladesh. Int. J. Health Manag. 2020, 13, 263-264. [CrossRef]

35. Nachega, J.B.; Mbala-Kingebeni, P.; Otshudiema, J.; Mobula, L.M.; Preiser, W.; Kallay, O.; Michaels-Strasser, S.; Breman, J.G.; Rimoin, A.W.; Nsio, J.; et al. Responding to the Challenge of the Dual COVID-19 and Ebola Epidemics in the Democratic Republic of Congo-Priorities for Achieving Control. Am. J. Trop. Med. Hyg. 2020, 103, 597-602. [CrossRef]

36. Moona, A.A.; Islam, M.R. Mucormycosis or black fungus is a new fright in India during covid-19 pandemic: Associated risk factors and actionable items. Public Health Pract. (Oxf. Engl.) 2021, 2, 100153. [CrossRef]

37. Black Fungus Detected in Covid-19 Survivors, 8 Lose Eyesight in Surat. India Today. 2021. Available online: www.indiatoday.in/ coronavirus-outbreak/story / black-fungus-mucormycosis-detected-covid19-survivors-8-lose-eyesight-surat-fungal-infectionsymptoms-1799971-2021-05-07 (accessed on 5 June 2021).

38. Bangladesh Reports 1st Death by Black Fungus. Available online: https://www.aa.com.tr/en/asia-pacific/bangladesh-reports1st-death-by-black-fungus / 2253604 (accessed on 18 July 2021).

39. Mottaleb, K.A.; Mainuddin, M.; Sonobe, T. COVID-19 induced economic loss and ensur-ing food security for vulnerable groups: Policy implications from Bangladesh. PLoS ONE 2020, 15, e0240709. [CrossRef] [PubMed]

40. Organisation for Economic Cooperation and Development. Social Economy and the COVID-19 Crisis: Current and Future Roles; OECD Publishing: Paris, France, 2020.

41. Uğur, N.G.; Akbıyık, A. Impacts of COVID-19 on global tourism industry: A cross-regional comparison. Tour. Manag. Perspect. 2020, 36, 100744. [CrossRef] [PubMed]

42. Hossain, M.S.; Hami, I.; Sawrav, M.S.; Rabbi, M.F.; Saha, O.; Bahadur, N.M.; Rahaman, M.M. Drug Repurposing for Prevention and Treatment of COVID-19: A Clinical Landscape. Discoveries 2020, 8, e121. [CrossRef] [PubMed]

43. Saha, O.; Hossain, M.S.; Rahaman, M.M. Genomic exploration light on multiple origin with potential parsimony-informative sites of the severe acute respiratory syndrome corona-virus 2 in Bangladesh. Gene Rep. 2020, 21, 100951. [CrossRef]

44. Singh, S.; Roy, M.D.; Sinha, C.P.; Parveen, C.P.; Sharma, C.P.; Joshi, C.P. Impact of COVID-19 and lockdown on mental health of children and adolescents: A narrative review with recommendations. Psychiatry Res. 2020, 293, 113429. [CrossRef]

45. Posel, D.; Oyenubi, A.; Kollamparambil, U. Job loss and mental health during the COVID-19 lockdown: Evidence from South Africa. PLoS ONE 2021, 16, e0249352. [CrossRef]

46. Fana, M.; Pérez, S.T.; Fernandez-Macias, E. Employment impact of Covid-19 crisis: From short term effects to long terms prospects. J. Ind. Bus. Econ. 2020, 47, 1-20. [CrossRef]

47. Nivette, A.E.; Zahnow, R.; Aguilar, R.; Ahven, A.; Amram, S.; Ariel, B.; Eisner, M.P. A global analysis of the impact of COVID-19 stay-at-home restrictions on crime. Nat. Hum. Behav. 2021, 5, 868-877. [CrossRef]

48. Ahamed Mim, M.; Naznin Rakhi, N.; Saha, O.; Rahaman, M.M. Recommendation of fecal specimen for routine molecular detection of SARS-CoV-2 and for COVID-19 discharge criteria. Pathog Glob. Health 2020, 114, 168-169. [CrossRef] [PubMed]

49. Ong, C.W.M.; Goletti, D. Impact of the global COVID-19 outbreak on the management of other communicable diseases. Int. J. Tuberc. Lung Dis. 2020, 24, 547-548. [CrossRef] [PubMed]

50. WHO I Human Infection with Avian Influenza A (H5N8)—The Russian Federation. WHO. Available online: http:/ /www.who. $\mathrm{int/csr/don/26-feb-2021-influenza-a-russian-federation/en/} \mathrm{(accessed} \mathrm{on} 5$ June 2021).

51. Glynn, J.R. Age-specific incidence of Ebola virus disease. Lancet 2015, 386, 432. [CrossRef]

52. Bower, H.; Johnson, S.; Bangura, M.S.; Kamara, A.J.; Kamara, O.; Mansaray, S.H.; Sesay, D.; Turay, C.; Checchi, F.; Glynn, J.R. Exposure-specific and age-specific attack rates for Ebola virus dis-ease in Ebola-affected households, Sierra Leone. Emerg. Infect. Dis. 2016, 22, 1403. [CrossRef] 
53. Yang, J.; Li, H. The impact of aging and COVID-19 on our immune system: A high-resolution map from single cell analysis. Protein Cell 2020, 11, 703-706. [CrossRef]

54. Davies, N.G.; Klepac, P.; Liu, Y.; Prem, K.; Jit, M.; Eggo, R.M. Age-dependent effects in the trans-mission and control of COVID-19 epidemics. Nat. Med. 2020, 26, 1205-1211. [CrossRef]

55. Dong, Y.; Mo, X.; Hu, Y.; Qi, X.; Jiang, F.; Jiang, Z.; Tong, S. Epidemiology of COVID-19 Among Children in China. Pediatrics 2020, 145, e20200702. [CrossRef]

56. Abbasi, J. Younger Adults Caught in COVID-19 Crosshairs as Demographics Shift. JAMA 2020, 324, 2141. [CrossRef]

57. Salvatore, P.P.; Sula, E.; Coyle, J.P.; Caruso, E.; Smith, A.R.; Levine, R.S.; Baack, B.N.; Mir, R.; Lockhart, E.R.; Tiwari, T.S.; et al. Recent increase in COVID-19 cases reported among adults aged 18-22 years-United States, 31 May-5 September 2020. Morb. Mortal. Wkly. Rep. 2020, 69, 1419. [CrossRef]

58. Liu, Y.; Mao, B.; Liang, S.; Yang, J.-W.; Lu, H.-W.; Chai, Y.-H.; Wang, L.; Zhang, L.; Li, Q.-H.; Zhao, L.; et al. Association between age and clinical characteristics and outcomes of COVID-19. Eur. Respir. J. 2020, 55, 2001112. [CrossRef]

59. Foeller, E.M.; Valle, C.C.R.D.; Foeller, T.M.; Oladapo, O.T.; Roos, E.; Thorson, E.A. Pregnancy and breastfeeding in the context of Ebola: A systematic review. Lancet Infect. Dis. 2020, 20, e149-e158. [CrossRef]

60. Bebell, L.M.; Oduyebo, T.; Riley, L.E. Ebola virus disease and pregnancy: A review of the current knowledge of Ebola virus pathogenesis, maternal, and neonatal outcomes. Birth Defects Res. 2017, 109, 353-362. [CrossRef] [PubMed]

61. Wastnedge, E.A.; Reynolds, R.M.; van Boeckel, S.R.; Stock, S.J.; Denison, F.C.; Maybin, J.A.; Critchley, H.O. Pregnancy and COVID-19. Physiol. Rev. 2021, 101, 303-318. [CrossRef]

62. Dos Santos, W.G. Impact of virus genetic variability and host immunity for the success of COVID-19 vaccines. Biomed. Pharmacother. 2021, 136, 111272. [CrossRef]

63. Zhou, P.; Liu, Z.; Chen, Y.; Xiao, Y.; Huang, X.; Fan, X.-G. Bacterial and fungal infections in COVID-19 patients: A matter of concern. Infect. Control. Hosp. Epidemiol. 2020, 41, 1124-1125. [CrossRef]

64. Menon, B.S. Black Fungus: Is Diabetes Behind India's High Number of Cases? BBC News. Updated 6 June 2021. Available online: https:/ / www.bbc.com/news/world-asia-india-57252077 (accessed on 7 June 2021).

65. Sugar, A.M. Mucormycosis. Clin. Infect. Dis. 1992, 14, S126-S129. [CrossRef]

66. Singh, A.K.; Singh, R.; Joshi, S.R.; Misra, A. Mucormycosis in COVID-19: A systematic review of cases reported worldwide and in India. Diabetes Metab. Syndr. Clin. Res. Rev. 2021, 15, 102146. [CrossRef] [PubMed]

67. Reddy, B.L.; Milton, H., Jr. The Causal Relationship between Eating Animals and Viral Epidemics. Microb. Physiol. 2020, 30, 2-8. [CrossRef] [PubMed]

68. Tong, Y.; Shi, W.-F.; Liu, D.; Qian, J.; Liang, L.; Bo, X.-C.; Liu, J.; Ren, H.-G.; Fan, H.; Li, M.; et al. China Mobile Laboratory Testing Team in Sierra The China Mobile Laboratory Testing Team in Sierra Leone; Genetic diversity and evolutionary dynamics of Ebola virus in Sierra Leone. Nat. Cell Biol. 2015, 524, 93-96. [CrossRef]

69. Boni, M.F.; Lemey, P.; Jiang, X.; Lam, T.T.Y.; Perry, B.W.; Castoe, T.A.; Robertson, D.L. Evolutionary origins of the SARS-CoV-2 sarbecovirus lineage responsible for the COVID-19 pandemic. Nat. Microbiol. 2020, 5, 1408-1417. [CrossRef]

70. Saha, O.; Islam, I.; Shatadru, R.N.; Rakhi, N.N.; Hossain, M.S.; Rahaman, M.M. Temporal landscape of mutational frequencies in SARS-CoV-2 genomes of Bangladesh: Possible implications from the ongoing outbreak in Bangladesh. Virus Genes 2021, 1, 1-13.

71. Lycett, S.J.; Duchatel, F.; Digard, P. A brief history of bird flu. Philos. Trans. R. Soc. B Biol. Sci. 2019, 374, 20180257. [CrossRef] [PubMed]

72. Lycett, S.J.; Pohlmann, A.; Staubach, C.; Caliendo, V.; Woolhouse, M.; Beer, M.; Kuiken, T. Genesis and spread of multiple reassortants during the 2016/2017 H5 avian influenza epidemic in Eurasia. Proc. Natl. Acad. Sci. USA 2020, 117, 20814-20825. [CrossRef] [PubMed]

73. France to Cull 600,000 Poultry to Stem Bird Flu. Reuters. Available online: https://www.reuters.com/business/healthcarepharmaceuticals / france-cull-600000-poultry-stem-bird-flu-2021-01-05/ (accessed on 9 June 2021).

74. Scoizec, A.; Niqueux, E.; Thomas, R.; Daniel, P.; Schmitz, A.; Le Bouquin, S. Airborne detection of H5N8 highly pathogenic avian influenza virus genome in poultry farms, France. Front. Vet. Sci. 2018, 5, 15. [CrossRef] [PubMed]

75. European Food Safety Authority. European Centre for Disease Prevention and Control and European Union Reference Laboratory for Avian Influenza, Adlhoch, C., Fusaro, A., Gonzales, J.L., Kuiken, T., Marangon, S., Niqueux, É., Staubach, C., Terregino, C., Muñoz Guajar-do I. Avian influenza overview December 2020-February 2021. EFSA J. 2021, 19 , e06497.

76. Govorkova, E.A.; McCullers, J.A. Therapeutics Against Influenza. Curr. Top. Microbiol. Immunol. 2011, 370, 273-300. [CrossRef]

77. Nabi, G.; Wang, Y.; Lü, L.; Jiang, C.; Ahmad, S.; Wu, Y.; Li, D. Bats and birds as viral reservoirs: A physiological and ecological perspective. Sci. Total Environ. 2021, 754, 142372. [CrossRef]

78. de Vries, R.D.; De Gruyter, H.L.; Bestebroer, T.M.; Pronk, M.; Fouchier, R.A.; Osterhaus, A.D.; Sutter, G.; Kreijtz, J.H.; Rimmelzwaan, G.F. Induction of influenza (H5N8) antibodies by modified vaccinia virus Ankara H5N1 vaccine. Emerg. Infect. Dis. 2015, 21, 1086. [CrossRef] [PubMed]

79. Ibrahim, M.; Zakaria, S.; Bazid, A.H.; Kilany, W.H.; El-Abideen, M.A.; Ali, A. A single dose of in-activated oil-emulsion bivalent $\mathrm{H} 5 \mathrm{~N} 8 / \mathrm{H} 5 \mathrm{~N} 1$ vaccine protects chickens against the lethal challenge of both highly pathogenic avian influenza viruses. Comp. Immunol. Microbiol. Infect. Dis. 2021, 74, 101601. [CrossRef] 
80. Ren, H.; Wang, G.; Wang, S.; Chen, H.; Chen, Z.; Hu, H.; Cheng, G.; Zhou, P. Cross-protection of newly emerging HPAI H5 viruses by neutralizing human monoclonal antibodies: A viable alternative to oseltamivir. Platf. Dev. Expr. Purif. Stable Isot. labeled Monoclon. Antibodies Escherichia Coli 2016, 8, 1156-1166. [CrossRef] [PubMed]

81. Baek, Y.G.; Lee, Y.N.; Lee, D.H.; Shin, J.I.; Lee, J.H.; Chung, D.H.; Lee, E.K.; Heo, G.B.; Sagong, M.; Kye, S.J.; et al. Multiple Reassortants of H5N8 Clade 2.3. 4.4 b Highly Pathogenic Avian Influ-enza Viruses Detected in South Korea during the Winter of 2020-2021. Viruses 2021, 13, 490. [CrossRef]

82. Chan, M. Ebola Virus Disease in West Africa-No Early End to the Outbreak. N. Engl. J. Med. 2014, 371, 1183-1185. [CrossRef] [PubMed]

83. Saeed, S.; Hasan, S.; Ahmad, S.A.; Masood, R. Ebola virus: A global public health menace: A narrative review. J. Fam. Med. Prim. Care 2019, 8, 2189-2201. [CrossRef] [PubMed]

84. Quaglio, G.; Goerens, C.; Putoto, G.; Rübig, P.; Lafaye, P.; Karapiperis, T.; Dario, C.; Delaunois, P.; Zachariah, R. Ebola: Lessons learned and future challenges for Europe. Lancet Infect. Dis. 2015, 16, 259-263. [CrossRef]

85. Gupta, S.; Gupta, N.; Yadav, P.; Patil, D. Ebola virus outbreak preparedness plan for develop-ing Nations: Lessons learnt from affected countries. J. Infect. Public Health 2021, 14, 293-305. [CrossRef] [PubMed]

86. Aruna, A.; Mbala, P.; Minikulu, L.; Mukadi, D.; Bulemfu, D.; Edidi, F.; Bulabula, J.; Tshapenda, G.; Nsio, J.; Kitenge, R.; et al. Ebola Virus Disease Outbreak-Democratic Republic of the Congo, August 2018-November 2019. Morb. Mortal. Wkly. Report 2019, 68, 1162. [CrossRef]

87. Adepoju, P. Ebola and COVID-19 in DR Congo and Guinea. Lancet Infect. Dis. 2021, 21, 461. [CrossRef]

88. Rojas, M.; Monsalve, D.M.; Pacheco, Y.; Acosta-Ampudia, Y.; Ramírez-Santana, C.; Ansari, A.A.; Gershwin, M.E.; Anaya, J.-M. Ebola virus disease: An emerging and re-emerging viral threat. J. Autoimmun. 2020, 106, 102375. [CrossRef]

89. Wolf, J.; Jannat, R.; Dubey, S.; Troth, S.; Onorato, M.T.; Coller, B.A.; Hanson, M.E.; Simon, J.K. Development of Pandemic Vaccines: ERVEBO Case Study. Vaccines 2021, 9, 190. [CrossRef]

90. Ullah, M.A.; Sarkar, B.; Islam, S.S. Exploiting the reverse vaccinology approach to design novel subunit vaccines against Ebola virus. Immunobiology 2020, 225, 151949. [CrossRef]

91. Yazdanpanah, Y.; Arribas, J.R.; Malvy, D. Treatment of Ebola virus disease. Intensive Care Med. 2015, 41, 115-117. [CrossRef]

92. Bishop, B.M. Potential and Emerging Treatment Options for Ebola Virus Disease. Ann. Pharmacother. 2014, 49, 196-206. [CrossRef]

93. Kiiza, P.; Mullin, S.; Teo, K.; Adhikari, N.K.; Fowler, R.A. Treatment of Ebola-related critical illness. Intensive Care Med. 2020, 46, 285-297. [CrossRef] [PubMed]

94. Markham, A. REGN-EB3: First Approval. Drugs 2021, 81, 175-178. [CrossRef] [PubMed]

95. Joe, P.; Ashutosh, M.S.; Gajapathiraju, C.; Asmita, G. The Journey of Remdesivir: From Ebola to COVID-19. Drugs Context. 2020, 9, 1-9.

96. Uyeki, T.M.; Mehta, A.K.; Davey, R.T., Jr.; Liddell, A.M.; Wolf, T.; Vetter, P.; Schmiedel, S.; Grünewald, T.; Jacobs, M.; Arribas, J.R.; et al. Clinical management of Ebola virus disease in the Unit-ed States and Europe. N. Engl. J. Med. 2016, 374, 636-646. [CrossRef]

97. Chakraborty, I.; Maity, P. COVID-19 outbreak: Migration, effects on society, global envi-ronment and prevention. Sci. Total. Environ. 2020, 728, 138882. [CrossRef]

98. Douglas, M.; Katikireddi, S.V.; Taulbut, M.; McKee, M.; McCartney, G. Mitigating the wider health effects of covid-19 pandemic response. BMJ 2020, 369, $\mathrm{m} 1557$. [CrossRef]

99. Islam, N.; Sharp, S.J.; Chowell, G.; Shabnam, S.; Kawachi, I.; Lacey, B.; Massaro, J.M.; Sr, R.B.D.; White, M. Physical distancing interventions and incidence of coronavirus disease 2019: Natural experiment in 149 countries. BMJ 2020, 370, m2743. [CrossRef] [PubMed]

100. Nussbaumer-Streit, B.; Mayr, V.; Dobrescu, A.I.; Chapman, A.; Persad, E.; Klerings, I.; Gartlehner, G. Quarantine alone or in combination with other public health measures to control COVID-19: A rapid review. Cochrane Database Syst. Rev. 2020, 4, CD013574

101. Heinz, F.X.; Stiasny, K. Profiles of current COVID-19 vaccines. Wien. Klin. Wochenschr. 2021, 133, 271-283. [CrossRef] [PubMed]

102. Gómez, C.E.; Perdiguero, B.; Esteban, M. Emerging sars-cov-2 variants and impact in global vaccination programs against sars-cov-2/covid-19. Vaccines 2021, 9, 243. [CrossRef] [PubMed]

103. Stasi, C.; Fallani, S.; Voller, F.; Silvestri, C. Treatment for COVID-19: An overview. Eur. J. Pharmacol. 2020, 889, 173644. [CrossRef]

104. Chibber, P.; Haq, S.A.; Ahmed, I.; Andrabi, N.I.; Singh, G. Advances in the possible treatment of COVID-19: A review. Eur. J. Pharmacol. 2020, 883, 173372. [CrossRef]

105. Rabby, M.I. Current drugs with potential for treatment of COVID-19: A literature review. J. Pharm. Pharm. Sci. 2020, 23, 58-64. [CrossRef]

106. WHO Director-General's Opening Remarks at the Media Briefing on COVID-19-22 June 2020. Available online: https: //www.who.int/director-general/speeches/detail/who-director-general-s-opening-remarks-at-the-media-briefing-oncovid-19---22-june-2020 (accessed on 10 June 2021).

107. Xu, X.; Han, M.; Li, T.; Sun, W.; Wang, D.; Fu, B.; Zhou, Y.; Zheng, X.; Yang, Y.; Li, X.; et al. Effective treatment of severe COVID-19 patients with tocilizumab. Proc. Natl. Acad. Sci. USA 2020, 117, 10970-10975. [CrossRef] [PubMed]

108. Lokugamage, K.G.; Hage, A.; Schindewolf, C.; Rajsbaum, R.; Menachery, V.D. SARS-CoV-2 sensitive to type I interferon pretreatment. BioRxiv 2020. [CrossRef] 
109. Walz, L.; Cohen, A.J.; Rebaza, A.P.; Vanchieri, J.; Slade, M.D.; Cruz, C.S.D.; Sharma, L. JAK-inhibitor and type I interferon ability to produce favorable clinical outcomes in COVID-19 patients: A systematic review and meta-analysis. BMC Infect. Dis. 2021, 21, 1-10. [CrossRef]

110. Rajendran, K.; Krishnasamy, N.; Rangarajan, J.; Rathinam, J.; Natarajan, M.; Ramachandran, A. Convalescent plasma transfusion for the treatment of COVID-19: Systematic review. J. Med. Virol. 2020, 92, 1475-1483. [CrossRef]

111. Sarkar, S.; Soni, K.D.; Khanna, P. Convalescent plasma is a clutch at straws in COVID-19 management! A systematic review and meta-analysis. J. Med Virol. 2021, 93, 1111-1118. [CrossRef] [PubMed] 